\title{
FORECASTING OF THE STOCK RATE OF LEADING WORLD COMPANIES USING ECONOMETRIC METHODS AND DCF ANALYSIS
}

\author{
Olena Nikolaieva, \\ Associate Professor, Cand. Phys.-Mat. of science Ukraine, V.N. Karazin Kharkiv National University; \\ Department of Economic Cybernetics and Applied Economics \\ http://orcid.org/0000-0002-1105-7227
}

\begin{abstract}
Anzhela Petrova,
Associate Professor, Cand. Phys.-Mat. of science Ukraine, V.N. Karazin Kharkiv National University; Department of Economic Cybernetics and Applied Economics

http://orcid.org/0000-0003-1773-1427

Rostyslav Lutsenko, Business Development Assistant, Singularex Limited Liability Company, Ukraine, Kharkiv, https://orcid.org/0000-0003-0737-3902
\end{abstract}

DOI: https://doi.org/10.31435/rsglobal_ijite/31052020/7067

\section{ARTICLE INFO}

Received 25 March 2020

Accepted 16 May 2020

Published 31 May 2020

\section{KEYWORDS}

DCF-model,

ARIMA-model,

autoregression,

forecasting,

financial analysis. \begin{abstract}
In this article, we will cover various models for forecasting the stock price of global companies, namely the DCF model, with well-reasoned financial analysis and the ARIMA model, an integrated model of autoregression moving average, as an econometric mechanism for point and interval forecasting. The main goal is to compare the obtained forecasting results and evaluate their real accuracy. The article is based on forecasting stock prices of two companies: Coca-Cola HBC AG (CCHGY) and Nestle S.A. (NSRGF). At the moment, it is not determined which approach is better for predicting the stock price - the analysis of financial indicators or the use of econometric data analysis methods.
\end{abstract}

Citation: Olena Nikolaieva, Anzhela Petrova, Rostyslav Lutsenko. (2020) Forecasting of the Stock Rate of Leading World Companies Using Econometric Methods and DCF Analysis. International Journal of Innovative Technologies in Economy. 2(29). doi: 10.31435/rsglobal_ijite/31052020/7067

Copyright: (C) 2020 Olena Nikolaieva, Anzhela Petrova, Rostyslav Lutsenko. This is an open-access article distributed under the terms of the Creative Commons Attribution License (CC BY). The use, distribution or reproduction in other forums is permitted, provided the original author(s) or licensor are credited and that the original publication in this journal is cited, in accordance with accepted academic practice. No use, distribution or reproduction is permitted which does not comply with these terms.

Introduction. Forecasting of market indicators of the value of stocks has been in demand and relevant since the inception of stock markets as the economic condition of individuals enterprises and the entire state depends on the ability to properly manage valuable financial assets. Making an informed decision regarding the purchase of a financial asset, investing in the development of a company involves determining the relevant price of a share and security. In order to correctly determine the price of a stock or a quotation of a stock exchange index, a decision maker (investor, trader, entrepreneur) must be able to analyze diverse economic information, clearly understand the factors that influence the valuation result and also have knowledge of the methods and approaches for forecasting the value of securities.

Traditionally, there are three main directions in the study and forecasting of financial assets: these are fundamental, technical and quantitative types of analysis. The last one containing both classical econometric methods for processing time series and directions that have arisen in the last 20-30 years and related to the application of theory chaos and artificial intelligence methods. All these methods have their 
advantages and disadvantages. Therefore, the question of choosing a particular method and its effectiveness under specific conditions remains debatable. It is relevant to study the applicability of certain methods for various issuers and different time periods, compare them, as well as take into account other factors affecting both the economic situation as a whole and an individual market or enterprise.

In this paper we compare the approaches of fundamental and quantitative analysis, namely, the discounted cash flow (DCF) method, which allows you to estimate the fair price of shares using a comprehensive financial analysis of the issuing corporation and the ARIMA time series forecasting model based on the consideration of previous levels of the series integrated moving average white noise.

Thus, the subject of this study is the stock prices of Coca-Cola and Nestle corporations. The purpose of this article is a comparative analysis of the predictive ability of discounted cash flow and ARIMA methods based on time series data from Coca-Cola HBC and Nestle S.A.

Review of literature. The most widespread methods for assessing the issuer's market value and forecasting the price dynamics of its securities are fundamental and technical analyzes. These methods have been known since the 20s of the last century. Later, from the mid-50s of the last century, quantitative methods of analysis joined them.

Fundamental analysis is an analysis of the financial and economic performance of companies and industries in order to assess the fair value of the subject of investment. Such an analysis focuses on data, on the size of assets, debt, revenue and net profit, dividend forecasts, as well as the company's risk assessment.

The American school of fundamental analysis is based on the classic work of Benjamin Graham and David Dodd, "Security Analysis" [1], published by them in 1934. The essence and procedures of fundamental analysis are described in the writings of such famous economists and entrepreneurs as W. Buffett [2], M. Thomsett [3], W. Sharp, G. Alexander and J. Bailey [4]. For example, M. Thomsett in [3] defines fundamental analysis as a process of studying the state of the economy, industry and financial condition of the issuer in order to determine the market value of the issuer's shares.

In this paper, a variety of fundamental analyzes were used such as DCF analysis or the discounted cash flow method. Its essence is that the discount rate is determined based on the analysis of cash flows. It requires return on equity investment in companies is assessed using the Capital Asset Pricing Model (CAPM). The dynamics of revenue is discounted taking into account the time coefficient determined by the Hamada model [5]. Then the perpetual value of the asset is determined, which is discounted to date. Using DCF analysis in [6], the fair price of shares of 10 Russian companies was calculated, including Gazprom and Rosneft. It was concluded that the proposed method allows to establish the deviation of the share price from the fair. The authors of [7] believe that the use of the DCF method for valuing Lukoil stocks yields unsatisfactory results and the target prices determined by forecasts do not correspond to the current market conditions.

Thus, critics reproach the DCF method, as well as other varieties of fundamental analysis in subjectivity and insufficient forecast accuracy. Setting the fair price for shares and determining the shares of which company have the highest profitability, fundamental analysis nevertheless does not take into account market fluctuations in prices and cannot establish the moment when it is necessary to purchase shares. Technical analysis can help to solve this issue, which is a price forecasting system based on information obtained from market trading. In contrast to the fundamental analysis, which is based on the study of the production activities of the enterprise, the basis of the technical analysis is the allocation and study of certain patterns in the movement of the quotation chart.

The technical analysis does not consider the reasons why the price changes direction (for example, due to low stock returns, price fluctuations for other goods or changes in other conditions), but only takes into account the fact that the price is moving in one direction or another, or in a certain way, for example, being within what price range for some time. Various techniques can also take into account trading volumes, the amount of open positions, the volume of submitted orders for the purchase / sale, etc.

"The fundamental difference between fundamental and technical analysis consists in the following: if the first one studies the causes of price movements, then the second - the very fact of price movements. The whole charm of technical analysis is that it can be used at any time and at any time interval." [8, p. 119]

Fundamental analysis, therefore, makes it possible to understand whether the stocks of a company are underestimated or overvalued at the moment. A technical analysis allows you to determine the best moment to conclude transactions. Fundamental is more used for long-term 
investments, while technical - for short-term speculative transactions in the market. Despite the widespread use, technical analysis is criticized due to the fact that the interpretation of stock trends by various experts is a subjective opinion.

Since the 50s of the XX century, many experts on the assessment of the movement of securities apply quantitative methods of analysis based on classical models of forecasting time series. Such methods include methods of simple and exponential smoothing, construction of growth curves, adaptive methods of Brown and Holt-Winters [9], [10]. The advantages of these methods include their simplicity and the fact that they do not use any information other than previous values of the number series to build forecasts. The disadvantages are sensitivity to outliers (peak or fall points of the indicator), the need to meet the requirements imposed on residuals (normality, uncorrelatedness, randomness, constancy of variance).

In 1976, a book by J. Box and G. Jenkins [11] was published, where fundamentally new approaches to the analysis of time series were proposed. The authors of [11] examined several hierarchical models for forecasting time series, the most famous of which is ARIMA (Autoregressive Integrated Moving Average) - a model of autoregression and integrated moving average. Autoregression in the model allows you to take into account the values of the previous levels of the time series, and the moving average covers and smooths out the possible extreme levels of the series. This model has versatility, flexibility and the ability to successfully describe all the features of stationary time series. In [12], it is pointed out that the disadvantages of this method are "labor and resource availability and identification of the most reliable and non-linear models". Due to its ability to extract for forecasting all the possible information inherent in the dynamics of the levels of a series, ARIMA is successfully used in cases where it is necessary to quickly build a short-term forecast and there is no way to delve into the study of many factors affecting the indicator under study. Since its inception, ARIMA has been quite popular and many researchers have used it to predict stock prices. In particular, predicting financial time series, namely the stock market, considering the problem of choosing the best ARIMA models, was done by K. Shangodoyin, R. Sivasamy and F. Adebayo [13]. Using the empirical method, they were able to identify the best models for forecasting the stock market in Botswana and Nigeria.

The limited predictive ability of traditional methods and the weakness of their theoretical base led financial experts and analysts to look for new tools for evaluating and forecasting stock prices. Thanks to this, two new directions of the study of dynamic financial series were formed - a direction based on the theory of deterministic chaos and a direction based on developments in the field of artificial intelligence (AI).

The first was based on the hypothesis of fractality of financial markets. Fractal markets are characterized by the self-similarity of stock dynamics trajectories, the presence of long-term correlations and trends, fluctuations between "fair" states and critical points. B. Mandelbrot [14] and E. Peters [15] conducted research on financial and stock markets using R / S analysis, calculating the fractal dimensions of market systems, and methods for recovering attractors. Despite the fact that the existence of chaotic modes of functioning of the markets enriched the arsenal of researchers, it has been and is being applied at the pre-forecast level, since it is fundamentally impossible for non-linear systems to make predictions with a sufficiently wide forecast horizon.

In our opinion, the most promising direction in forecasting financial markets is Artificial Neural Networks ANN. A neural network is a mathematical object that consists of structures similar to brain neurons and simulates the activity of the nervous system. Computer programs that implement the neural network approach for forecasting stock market prices of stocks appeared in the late $80 \mathrm{~s}$ - early 90s of the last century and are now also quite popular. An important feature of ANN is that when they are used, restrictions related to the non-linear nature of the processes occurring in the stock market, as well as to the normal distribution, are removed. Each model self-organizes depending on the initial data. Neural networks are data driven and self-adaptive in nature [15]. However, despite the obvious advantages of neural networks over other modeling tools, [16] notes "Despite the greater number of advertising statements about the success of their (neural networks) application on the stock market, real practice, as a rule, shows opposite results. As a result, the most successful investors usually do not recommend their use referring to their inefficiency."

This review showed that each group of methods has its advantages and disadvantages; therefore, to build a qualitative forecast it is better to use methods that complement each other, in particular, the comprehensiveness of the DCF analysis and the flexibility of the ARIMA model. 
Analysis/study/results. Financial analysis Coca Cola HBC.

Revenue growth. In 2018 Coca-Cola HBC's sales reached $€ 6657.1$ million, with a growth of $2.1 \%$. The increase in operating efficiency contributed to the fact that the company's operating profit margin increased by 56 basis points, reaching a margin of 9.6\% in 2018 (compared with $9.04 \%$ in 2017). In a period from 3 to 5 years, we are optimistic about the ability of business to expand its sales beyond the existing limits.

Segments Revenue and EBIT. Coca-Cola HBC has historically divided its market into three main segments: Established, Developing and Emerging. In 2018, the largest percentage of total revenue came from Emerging markets 43\%, then from Established markets 37\% and 20\% from Developing markets. We forecast that overall segment revenue ratio will change in the direction of increasing the share of revenue in 2024 in Emerging markets by 2\% and its decrease in Established markets by $2 \%$. This situation is due to the fact that Established markets are already developed ones, and Emerging markets are the largest market in terms of population, and they have the greatest growth potential.

Reported earnings and financial soundness of COCA-COLA HBC. We've conducted Beneish M-score and Altman-Z score analyses to evaluate earnings quality and assess Coca-Cola HBC financial health. Altman Z-Score for Coca-Cola HBC was greater than 2.95 over the last four years, which indicates that Coca-Cola HBC is safe from bankruptcy. Based on our assessment of Beneish MScore for Coca-Cola HBC, we conclude that there is a low probability of Coca-Cola HBC manipulating reported earnings over the last five years since the score was below the benchmark M-Score of -2.22.

Financial performance. In 2019, the ratio of net debt to equity was 1.12 (the total debt of the company amounted to $€ 3608.43$ million in 2019), and we expect this figure to drop to 1.11 in 2020 due to an increase in total debt. We associate this with the company's purchase of two companies - Bambi and Lurisia ones [17]. We also expect this indicator to increase over the next five years.

The ratio of net debt to EBITDA over the past five years has decreased from 2.84 in 2014 to 1.66 in 2018, so we can say that the company has good solvency. This position is confirmed by the ratio of long-term debt to total assets. During the analyzed period, the indicator was stable (0.21 in 2018).

A firm liquidity position is maintained by the current ratio and quick ratio. Since 2014, the current liquidity ratio has grown from 0.94 to 1.21 in 2018 , and the quick ratio to 0.75 to 0.98 . This proves to us that the company can repay current debt from its current assets. In addition to its compelling current and quick liquidity ratio, Coca-Cola $\mathrm{HBC}$ has a robust cash pillow of around $10 \%$ of total assets in 2018.

Working capital has been growing since 2016 from $€ 93.2$ million to $€ 419.6$ million in 2018. It is assumed that working capital will grow faster starting in 2019 , reaching $€ 1,026.28$ million as early as in 2024 . The company can direct this money to expand its production through the purchase of new enterprises.

EBITDA margin grows over the analyzed period from $11.40 \%$ in 2014 to $14.55 \%$ in 2018 . We forecast a steady annual growth rate of this indicator.

\section{Financial analysis Nestlé SA}

Robust earnings growth. Stable growth in profit margins is anticipated over the forecasted period. Nestlé managed to strengthen its balanced growth model and anchored profitable growth in a sustainable manner in the first half of 2015. We are confident about the ability of the business to expand sales beyond the existing limits in a period of 3 to 5 years. We also anticipate that the company should finally break the psychological barrier of revenue of 100 billion CHF in the next 5 years. As a result of our investigation, based on the current dynamics of the company's main financial indicators, we are able to claim that annual revenue growth will reach $2 \%$ in 2020 and increase smoothly by 2024 up to $2.5 \%$.

Profit margins increasing. The main attractiveness of Nestlé for investors is that a shareholder can get low-risk equity with a strong financial background. Earnings performance of the company is stable. Organic growth is projected to remain at $3 \%$ per year. Organic growth will be $1-1.5 \%$ in the developed markets and more than 5\% in the emerging markets. Accordingly, there will be a robust growth of all profitability ratios. Gross profit margin amounts to more than 50\% in 2017 . We also emphasize that this indicator will grow by 2024 up to $52.5 \%$. We expect that EBITDA in 5 years will exceed $16.2 \%$ of revenue and in the future will gradually approach $20.9 \%$ and remain stable. We are convinced that that EBITDA will increase due to the overall growth of sales, interest expenses and taxes. This positive outlook is largely underpinned by the exceptional uniqueness and scale of Nestlé, which is unrivaled. 
Profitability. Nestlé has the highest gross margins in food industry. Its $51 \%$ gross margins allow it to invest in advertising and innovation, both of which are key factors for the long-term survival of FMCG companies. However, at the EBIT margin level, the company is below the peer average, with 15\% EBIT margin in 2017. On the whole, company's EBIT margin has stalled in the most recent years, and in 2017 EBIT margin was 14.7\%. Input boost pressure and restructuring costs are the main causes of margins stagnation. In September, 2017 Nestlé set the first margin target in its history and started a cost efficiency program with the aim to raise EBIT margins to $18-20 \%$ by 2020 . Hence, judging by the current position, the company is able to achieve this goal.

Cash conversion at Nestlé is below the long-term industry average at $\sim 85 \%$, however, it has improved by $\sim 700$ bps between 2008 and 2018, through working capital efficiencies and a reduction in Capex. We also examine whether operational performance at Nestlé, measured by sales by the factory, reflects improving the efficiency of operational assets.

Debt and divide trend. Nestle has historically spent CHF 1 billion - CHF 3 billion of its roughly CHF 10 billion in annual free cash flow on bolt-on deals [18]. The Group has also used cash to repurchase shares in recent years. Nestle generates around CHF 4 billion per year in free cash flow after the dividend having been paid. We assume share buybacks will be financed through long- and short-term debt in equal proportion and Nestle could still deleverage down to 1.2 times Net Debt/EBITDA by fiscal 2024 due to its improved profitability, leaving ample room for large acquisitions.

\section{Valuation Coca Cola HBC}

Target price [19]. Our target price list for Coca Cola HBC is 35.4 Euros, that is, we believe that the share price will increase by $16.7 \%$ compared to 30.17 on $12 / 31 / 2019$. We evaluated the target price using two methods of comparative analysis and DCF, we got the final value by multiplying the result of each currency value method by weights (for both equal 0.5 , so as not to give preference to anyone) and summing up we got our result.

DCF. WACC. From the data provided by this company, we received corresponding Total Enterprise Value Calculation. The tax rate in the model is $25.4 \%$, it was predicted on the grounds of historical data. Cost of Equity amount of $9.8 \%$ was obtained using CAPM methods. As a result, we have such parameters for the weighted average cost of capital equal to $9.4 \%$.

CASES [20]. For 2013-2019, CAGR for Total Revenue was $-0.03 \%$, for the EBITDA parameter it was $4.8 \%$, the EBITDA margin for this period increased from $11 \%$ to $14.6 \%$.

BASE CASE. In this scenario, we assume that for 2019-2024, CAGR for Total Revenue will be $1 \%$, the forecast is based not on the trend of the entire sample, but with a review of recent years (where CAGR was significantly higher), since this better reflects the current development trend of the company, CAGR for EBITDA in this case is expected to be $2.2 \%$, while the margin will increase to $15.44 \%$. In this case, the PV Terminal Value is equal to 14,147 million Euros, taking into account the fact that as the multiplier we took the predicted value of the multiplier $\mathrm{P} / \mathrm{E}=20 \mathrm{x}$. If we take the median value of the competitors (24.6x), it turns out that the stock rating is not adequately high (checked using the Gordon model), so we decided that such a multiplier value is not suitable for our company.

BULL CASE. For a positive development scenario, where we took more optimistic growth values, we got such values for the corresponding parameters: CAGR (Total Revenue) $=3.5 \%$, CAGR $($ EBITDA $)=8.6 \%$, EBITDA margin $=18.5 \%$, PV Terminal Value $=19,183$ million $(20 x$ multiplier $)$

BEAR CASE. The growth rates for this option were chosen more pessimistic, but so that the absolute discrepancy with the BASE CASE was similar to the BEAR CASE, to be fair and not to give preference to any option. Results: CAGR (Total Revenue) $=-2.6 \%$, CAGR $($ EBITDA) $=-5.7 \%$, EBITDA margin $=12.4 \%$, PV Terminal Value $=9501$ million (20x multiplier).

SENSITIVITY ANALYSIS. Sensitivity analysis was carried out for stock prices depending on the size of the WACC and Terminal EBITDA Multiple. The maximum value (45.3 Euros per share) is obtained at WACC $=8.5 \%$ and the multiplier is $22 \mathrm{x}$, the minimum (34 Euros per share) at $10.5 \%$ and $18 \mathrm{x}$, respectively. The first option is especially interesting, as in this case the stock remains attractive even if the shareholder wants to receive a profit in the flesh of up to $20 \%$.

\section{Valuation method and risk statement Nestlé SA}

Nestlé's profitability is derived from sales to consumers and therefore is subject to variances in consumer income and confidence. As for an international company, its results, reported in Swiss francs, are subject to exchange rate movements. The Group has been actively acquiring and disposing of operations, 
and in the future further such activity could impact financial performance, both - upside and downside. The declining popularity of confectionery category and competitive pressures are other potential risks.

Market approach has $25 \%$ weight, which includes relative public and transaction multipliers, and Discounted Cash Flow (DCF) analysis as an intrinsic value approach with $75 \%$ weight to determine the target share price for Nestlé S.A. Therefore, our valuation arrives at $90.5 \mathrm{CHF}$ target price.

DCF model. We consider the price obtained using DCF model to be assigned more weight than due to market approach, which does not exclude short-term distorting market fluctuations. We consider this method to be more fundamental and based on a long-term perspective considering different scenarios.

Cost of equity calculation. In order to calculate equity cost we use Capital Asset Pricing Model (CAPM). It derives $5.5 \%$ cost of equity including the next indicators: Risk-free rate $-1.72 \%$, according to Aswath Damodaran methodology and his "Risk-free Rates based upon Differential Inflation" value. Market premium - 5,37\%, Aswath Damodaran, Equity Risk Premium by Country - July 2018. Country risk premium $-0,6 \%$, calculated as weighted average of main countries' risk premiums weighted with $\%$ of sales. Beta-0,6 (that means that the share price will be less volatile than the market).

WACC calculation. To calculate it, we make an assumption that tax rate equals average of the last 7 years $-28.8 \%$.

Base, bull and bear cases. The Base case is based on the main forecast values of Revenue growth with 2.5\% CAGR since 2020 till 2024, EBITDA 4.8\% CAGR. We assume that such growth is driven by organic growth of the main product groups. Another key driver of our valuation is a margin. Based on the results, EBITDA margin expansion is to be 18,23\% in 2024. Unlevered Free Cash Flow CAGR over 2020-2024 years equals 8.6\% (for comparison, CAGR in 2013-2018 is 7.5\%). The research was conducted using exit multiple approach (EV/EBITDA) to derive PV Terminal Value. PV Terminal Value with 19x EV/EBITDA appears 279 215m CHF.

Optimistic case main assumption is Total revenue growth with 4\% CAGR over 2020-2024. This high growth is driven by capturing new gradually gaining demand markets: raw food, sugar-and gluten-free confectionary, organic and non-GMO food ones. Also, it implies the implementation of product and business model innovations, investment in high-growth categories (such as coffee) and regions (emerging markets) Unlevered Free Cash Flow CAGR 2020-2024-11.5\%. EBITDA margin is also much higher and equals $20 \%$. It could be reached with a strict cost-cutting strategy, production technology modernization and operating costs lowering.

Indicators in bear case: EBITDA 1.7\% CAGR 2020-2024 and EBITDA margin starting at the lowest (of 2014-2019) level in 2020, reaches 16,4\% (current level) in 2024. Average total revenue growth rate $-1.4 \%$. This is due to a strong impact of the main risks, and competition in the most profitable sectors.

Sensitivity analysis. Sensitivity analysis is conducted with regard to EV/EBITDA and WACC changes, as the decisive factors in price determining. With WACC equal to 4,5\% and EV/EBITDA $19,5 \mathrm{x}$ the highest price reaches $100 \mathrm{CHF}$. This case has a considerable possibility since WACC is dependent on calculation methods and accuracy, for instance, the widely spread approach in CAPM (important WACC's part) calculation is taking government bond yield as a risk-free rate, which significantly lows the WACC value.

Modeling the share price of international corporations using ARIMA tools

To model the trend of Coca-Cola shares, we will take data for the last 7 years (2013-2020 daily data). Below is figure 1 of the dynamics of opening prices.
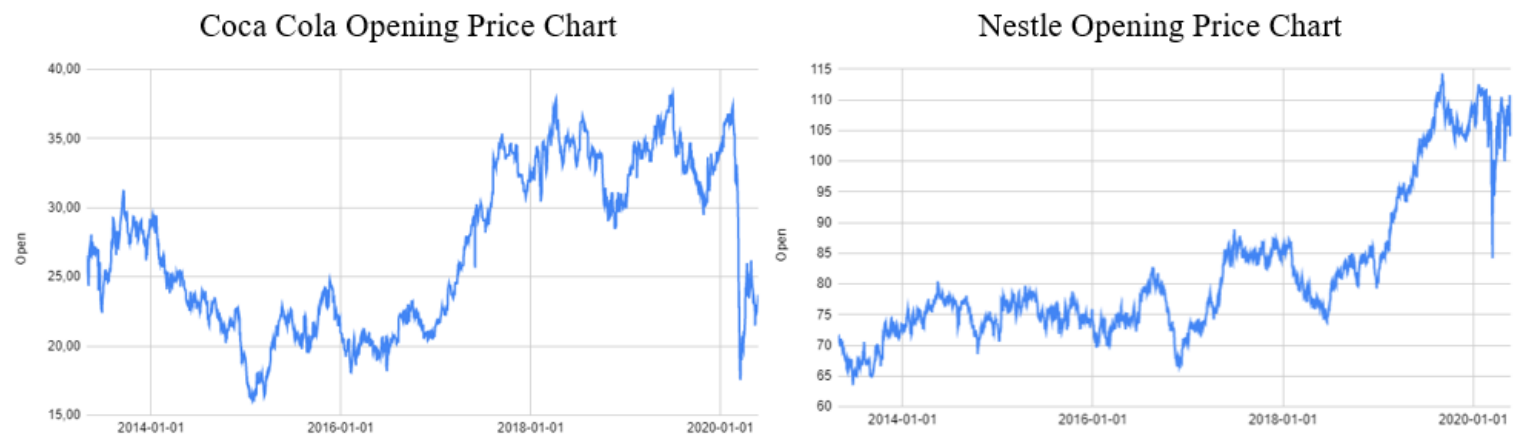

Fig.1. Coca-Cola and Nestle Daily Stock Price History [21, 22] 
Verification of time series for stationarity using the extended Dickie-Fuller test showed that both series are stationary with a 95\% confidence level, because the corresponding p-value is much less than 0.05. Dickie-Fuller's criterion for Coca-Cola was -12.72, and for Nestle -12.99. Lag order in both cases was 11 .

ARIMA (p, d, q) and auto arima models were built. To choose between several models, the Akaike information criterion (AIC) and the Bayesian information criterion (BIC) (Schwartz criterion) were used. In addition, the indicators of the quality of approximation of actual data by the model were analyzed on the basis of the following criteria:

1) $M A E=\frac{1}{n} \sum_{i=1}^{n}\left|y_{i}-\hat{y}_{i}\right| \quad-$ average absolute error (MAE),

2) $M A P E=\frac{100 \%}{n} \sum_{i=1}^{n}\left|\frac{y_{i}-\hat{y}_{i}}{y_{i}}\right|-$ the average relative error of the model (MAPE).

The remnants of the ARIMA models were tested for stationarity using the Jarque-Bera and Ljung-Box tests. One can see a direct comparison of ARIMA models in the figure 2. Table 1 shows the main statistical metrics.

Table 1. Training set error measures, own development in $\mathrm{R}$

\begin{tabular}{|l|c|c|}
\hline \multicolumn{1}{|c|}{ Training set error measures } & $\begin{array}{c}\text { Coca Cola } \\
\text { AUTO-ARIMA }(1,1,0)\end{array}$ & $\begin{array}{c}\text { Nestle } \\
\text { AUTO-ARIMA (4,1,3) }\end{array}$ \\
\hline Mean Error & 0.0052671 & 0.0000587 \\
\hline Mean Absolute Error & 0.2991474 & -0.5559536 \\
\hline Mean Percentage Error & 0.0012661 & -0.0111564 \\
\hline Mean Absolute Percentage Error & 1.1527830 & 0.7102487 \\
\hline Mean Absolute Scaled Error & 1.0090430 & 0.9920984 \\
\hline Autocorrelation of errors at lag 1 & -0.0002624 & 0.0000493 \\
\hline
\end{tabular}

In general, the models built using auto-arima are satisfactory and adequate. In Figure 2 we can see the result of building auto-arima for the two companies, as well as the best models showing a growing trend that is comparable to the Bull case and a downtrend that are comparable to the Bear case. ARIMA modeling has an advantage over DCF analysis in that it shows us the trend and confidence interval with different probabilities. Thus, we can see the forecast in any time period, and not just at a specific moment, for example, in a year or more.

Conclusions for financial analysis and DCF models of two companies. The research has shown that, considering Nestlés strong balance sheet, stable dividend growth and high profitability margins over the next five years, the company's stock will be an attractive investment for the subject holding period.

It is also necessary to emphasize the influence of the main risk for Nestlé, which is represented by the market, oversaturated with competitors. Intensive competition reveals the weaknesses of the company due to negative scale effect. The Group needs to implement a list of tools specific for smaller firms that contribute to flexible and effective management, as well as accelerating the response to rapidly changing market trends.

Several methods are needed to assess the current situation of Nestlé from different points of view, which in turn improves the quality of the resulting forecasts. We've applied a combination of two basic approaches in order to determine the target price. Discounted Cash Flow analysis as an intrinsic value approach gave a higher value, than the market approach, which includes public and transaction multipliers. The market approach arrives at price that is $10 \%$ lower than the current share price. It can be considered as a sign of overvalued Nestlé's share price. More fundamental and longterm perspective based on DCF analysis method (Base case) arrives at 12\% premium estimated price. 


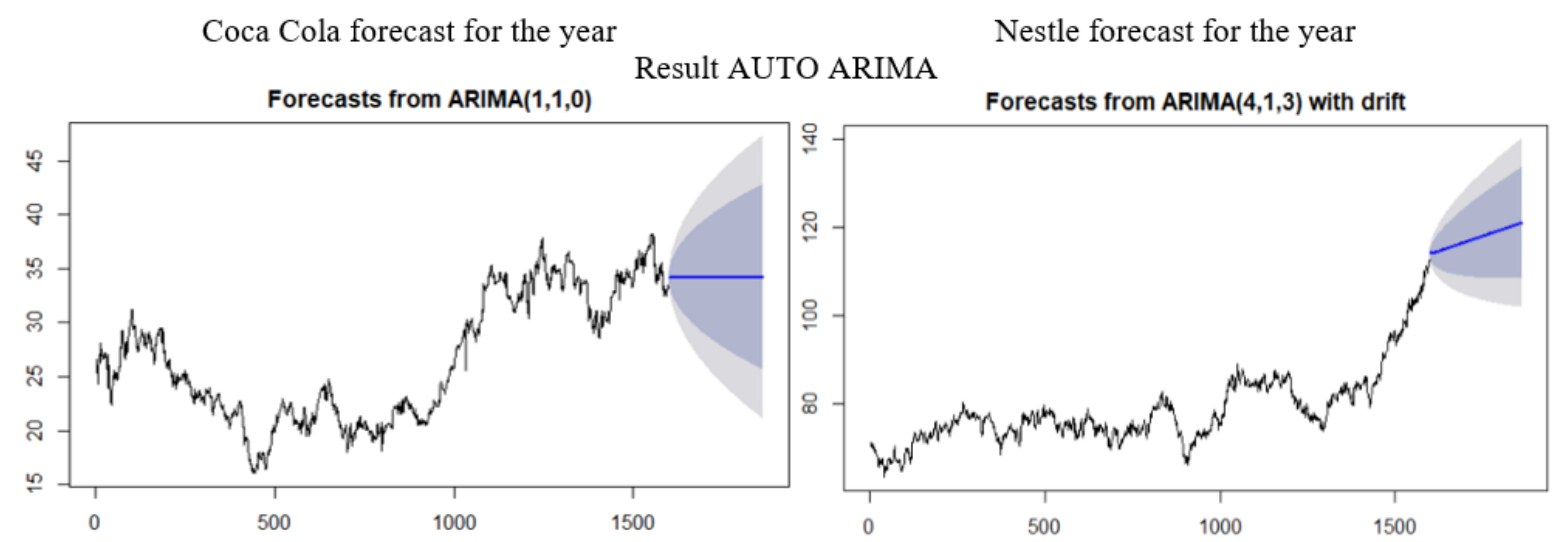

The result of the best growing prediction of manual ARIMA
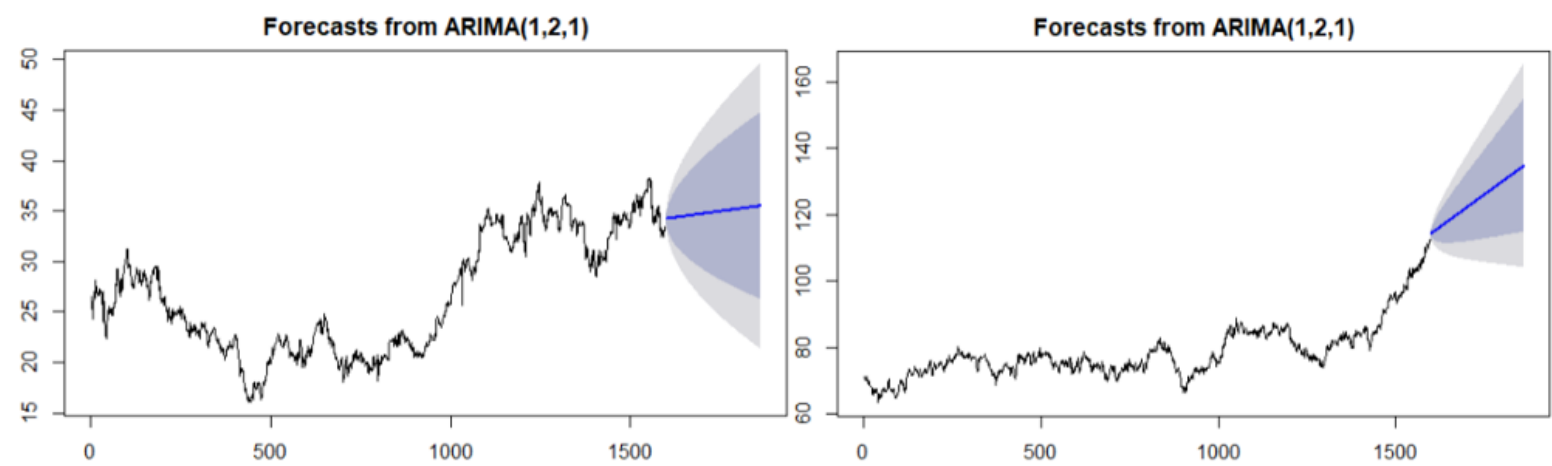

The result of the best downward prediction of manual ARIMA
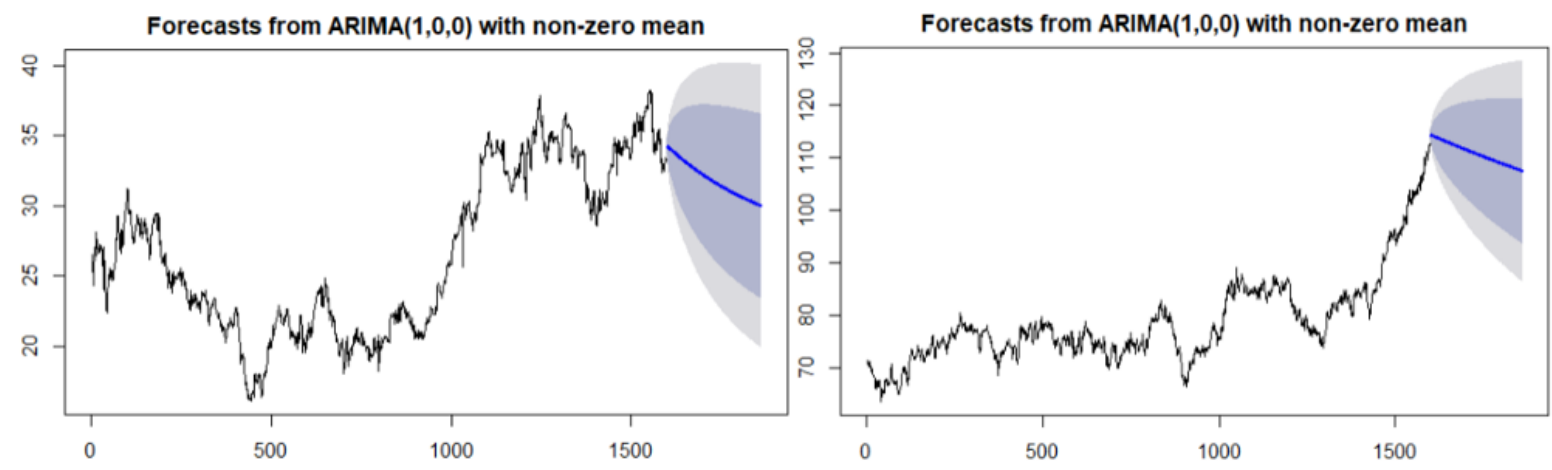

Fig. 2. Visualization of auto-arima results and the best manual models with growing and descending trends, own development in $R$

Similar work has been done for Coca-Cola HBC. In 2018 Coca-Cola HBC's sales reached $€ 6.65$ billion, with $2.1 \%$ of growth. Over the next 3-5 years, we are optimistic about the ability of the business to expand its sales beyond the existing limits. 2020 should be more successful for Coca-Cola HBC than 2019. We expect annual revenue growth of $2.7 \%$ in 2020 and continuation of smooth increase in future periods. EBITDA has been increasing steadily over the recent years, and is expected to increase in 2020, reaching $14.76 \%$ (compared with $14.55 \%$ in 2019). Our Beneish M-score and Altman Z-score analyses showed that Coca-Cola HBC does not manipulate reported earnings and is safe from bankruptcy.

As a result of ARIMA modeling, we can see a strong resemblance to the base, bull and bear scenarios. It is impossible to build model that is suitable for forecasting the shares of a large number of companies without conducting at least a superficial economic analysis. ARIMA models, in our opinion, can complement DCF analysis. DCF analysis helps to understand the current situation for a particular company in the industry and to understand the trend of its development. This will help in selecting parameters for the ARIMA model.

Both approaches have a number of advantages and disadvantages. Financial analysis requires significant human intervention with specific knowledge of the economics and particular industry. For the 
analysis of several world giants, building a DCF model seems to be the best solution that can provide accurate results. In order to select a few priority companies from hundreds or even thousands, you will need to turn to the rapidly evolving approaches to machine learning - artificial neural networks, recurrent neural networks with long short memory or to build a model of autoregression - moving average.

\section{REFERENCES}

1. Грэхем Б., Додд Д. Анализ ценных бумаг / Б. Грэхем, Д. Додд. - М.: Вильямс, 2012. - Изд. 3-е // Перевод. А. Назаренко, О. Пелявский. - 880 с.

2. Cunningham L., Buffet W. The Essays of Warren Buffet: Lessons for Corporate America /selected, arrange and introduced by Lawrence A. Cunningahm. - 3d ed. 308 p.

3. Thomsett, M. C. Mastering Fundamental Analysis: How to Spot Trends and Pick Winning Stocks Like thePros. [Текст] / - Dearborn Financial Publishing, Inc., 1998. p. 256.

4. W. G. Sharpe, G. J. Alexander, J. V. Bailey. Investments The Fifth Edition. Prentice Hall International. Inc 1995. $1028 \mathrm{p}$.

5. Hamada R.S. (1972). «The effect of the firm's capital structure on the systematic risk of common stocks». The Journal of Finance, Vol. 27, No. 2, pp. 435-452.

6. Меньшиков C.M. Модельные расчеты справедливых цен акций российских компаний на основе DCF и проверка их корректности // Управление корпоративными финансами. - 2014. - v 02(62). - c. 94-113

7. Жабунин А.Ю., Иевлева Н.В., Чередниченко И.А., Соколова А.В. Исследование применения метода DCF для определения целевых цен акций российских публичных корпораций // Российское предпринимательство. — 2016. - Т. 17. — № 24. — c. 3643-3656. — doi: 10.18334/rp.17.24.37205

8. Таран В.А. Играть на бирже просто?! / В.А. Таран. - СПб.: Питер, 2005. - c. 240

9. Steel A. Predictions in Financial Time Series Data: Doctoral dissertation/University at Albany. Albany, NY, 2014. $192 \mathrm{p}$.

10. Лукашин Ю.П. Адаптивные методы краткосрочного прогнозирования временных рядов: уч. пособие // Ю.П. Лукашин. - М.: Финансы и статистика, 2003. - 416 с.

11. Box G. E. P. and Jenkins G. M. Time Series Analysis, Forecasting and Control, rev. Ed., San Francisco: Holden-Day, 1976.

12. А.О. Долгіх, О.Г. Байбуз. Аналіз методів, моделей та програмних засобів прогнозування часових рядів / Открытые информационные и компьютерные интегрированные технологии, № 79, 2018. - с. 74-87

13. F. Adebayo Forecasting Stock Market Series with ARIMA Model [Electronic Resource] / F. Adebayo, R. Sivasamy, K. Shangodoyin // Journal of Statistical and Econometric Methods, vol.3, no.3 - 2014. - p. 65-77. Available in:

https://www.researchgate.net/publication/301559861_Forecasting_Stock_Market_Series_with_ARIMA_Model

14. Мандельброт Б. (Не)послушные рынки. ФРАКТАЛЬНАЯ революция в финансах. / Мандельброт Б., Хадсон Р., - М.: Изд. дом «Вильямс», 2006.

15. Петерс Э. Фрактальный анализ финансовых рынков. Применение хаоса в инвестициях и экономике. / Петерс Э. - М.: Интернет-трейдинг, 2004.

16. Adhikari R. An Introductory Study on Time Series Modeling and Forecasting. Journal of Artificial Intelligence. 2009. Vol. 42, No. 5. p.856-874

17. Demirel E., Atakisi A., Atmaca M. Financial and economic factors affecting debt ratio and ROE; ISE tourism firms case. European Journal of Scientific Research, 2011. 61(3), 458-466.

18. Official cite of The Nielsen Company. [Electronic resource]. - Access mode: https://www.nielsen.com

19. Damodaran Aswath. Damodaran on Valuation. 2nd edition. - Wiley, 2006. - 696 p.

20. Луценко Р., Доценко О., Іванкіна О. Інвестиційний аналіз найбільшого в світі виробника продуктів харчування // Вісник Харківського національного університету імені В. Н. Каразіна серія «Економічна». 2019. № 96. с. 95-102.

21. Financial data and news aggregator finance.yahoo.com: Coca-Cola HBC AG (CCHGY), Historical Data Access mode: https://finance.yahoo.com/quote/CCHGY/history?p=CCHGY.

22. Financial data and news aggregator finance.yahoo.com: Nestle S.A. (NSRGY), Historical Data - Access mode: https://finance.yahoo.com/quote/NSRGY/history?p=NSRGY 